This item was submitted to Loughborough's Research Repository by the author.

Items in Figshare are protected by copyright, with all rights reserved, unless otherwise indicated.

\title{
Degas in pieces: Form and fragment in the late Bather pastels
}

PLEASE CITE THE PUBLISHED VERSION

https://doi.org/10.29411/ncaw.2018.17.2.5

PUBLISHER

Association of Historians of Nineteenth-Century Art $@$ Nineteenth-Century Art Worldwide

VERSION

VoR (Version of Record)

\section{PUBLISHER STATEMENT}

This work is made available according to the conditions of the Creative Commons Attribution-NonCommercial 4.0 International (CC BY-NC 4.0) licence. Full details of this licence are available at: http://creativecommons.org/licenses/by-nc/4.0/

\section{LICENCE}

CC BY-NC 4.0

\section{REPOSITORY RECORD}

Brown, Kathryn. 2018. "Degas in Pieces: Form and Fragment in the Late Bather Pastels". figshare. https://hdl.handle.net/2134/35432. 


\section{Nineteenth-Century Art Worldwide}

a journal of nineteenth-century visual culture

\section{Degas in Pieces: Form and Fragment in the Late Bather Pastels}

Kathryn Brown

Nineteenth-Century Art Worldwide 17, no. 2 (Autumn 2018)

Citation: Kathryn Brown, "Degas in Pieces: Form and Fragment in the Late Bather Pastels," Nineteenth-Century Art Worldwide 17, no. 2 (Autumn 2018), https://doi.org/10.29411/ ncaw.2018.17.2.5.

Published by: Association of Historians of Nineteenth-Century Art

Notes:

This PDF is provided for reference purposes only and may not contain all the functionality or features of the original, online publication.

License:

This work is licensed under a Creative Commons Attribution-NonCommercial 4.0 International License Creative Commons License.

Accessed: 16 October 2018 


\section{Degas in Pieces: Form and Fragment in the Late Bather Pastels by Kathryn Brown}

In the final decades of his career, Edgar Degas undertook an innovative set of pictorial experiments in pastel. Having used this medium to portray female ballet dancers, bathers, and horseracing scenes throughout the 1870s and 1880s, he later turned to it for the purpose of exploring ways in which an image relates to its material support. During the 1890 s and the years immediately following the turn of the century, Degas challenged the compositional and communicative integrity of the artwork by pinning together pieces of paper, mounting them on card, and developing motifs over joins between the segments. By employing this accretive method of construction, he systematically altered and expanded the visual field of his works during the process of their production. This article examines the relevance of this technique to Degas's practice and locates his late pastels within debates about the role of the "fragment" in mid- to late nineteenth-century art critical discourses. I shall argue that focusing on Degas's decision to create works "in pieces" is important for understanding both his place in nineteenth-century art history and the legacy of his oeuvre in European modernism.

Historians have examined the importance of serial thinking in Degas's late pastels, noting in particular the repetition of form in the artist's portrayals of ballet dancers and female nudes. [1] Working on tracing paper (papier calque) or pulling counterproofs of a drawing by pressing dampened paper onto its surface and transferring the resulting image to a new support enabled Degas to recontextualize motifs in myriad ways. Throughout the late works, individual bathers can be found in similar poses in different settings, portrayed in contrasting color schemes, or against divergent background fictions. A single drawing could, therefore, both anchor a picture and serve as the basis of a subsequent set of experiments (figs. 1-4). This strategy was not, as Richard Kendall notes, an act of simple replication, but rather a compositional practice that enabled Degas to produce "endlessly nuanced variations and some radical transformations" of a single subject.[2] As Degas worked increasingly within the studio walls, this style of production also reduced his reliance on the presence of a model. Just as he is known to have used photographs as the starting points for certain images, so too he recycled drawings for the purpose of exploring combinatorial possibilities of form and setting while remaining committed to the depiction of the human body.[3] 


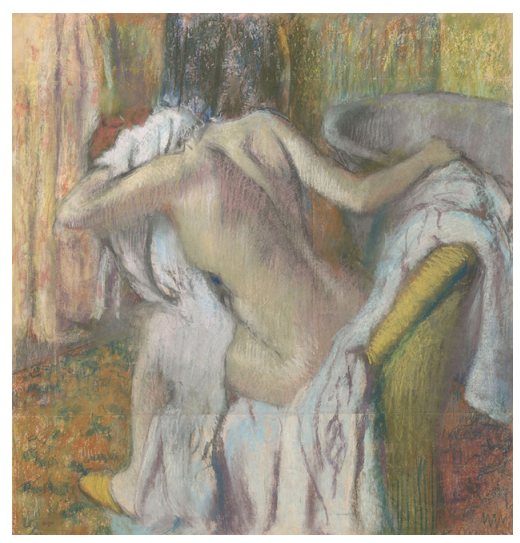

Fig. 1, Edgar Degas, After the Bath, Woman Drying Herself, ca. 1890-95. Pastel on wove paper laid on millboard. The National Gallery, London. Artwork in the public domain; available from: the National Gallery, London. [larger image]

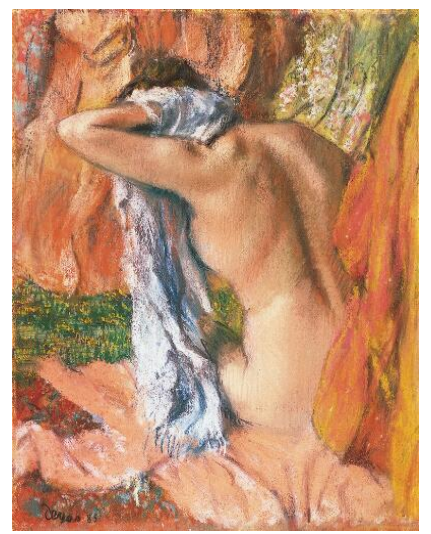

Fig. 2, Edgar Degas, After the Bath, ca. 1890-93. Pastel on paper mounted on cardboard. The Norton Simon Foundation, Pasadena. Artwork in the public domain; available from: the Norton Simon Foundation. [larger image] 


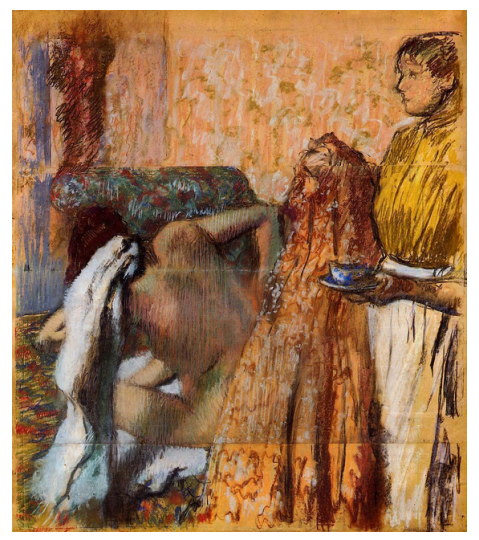

Fig. 3, Edgar Degas, Breakfast After the Bath, ca. 1893-98. Pastel on tracing paper. Kunstmuseum Winterthur, Winterthur. Artwork in the public domain; available from: the.athenaeum.org.

[larger image]

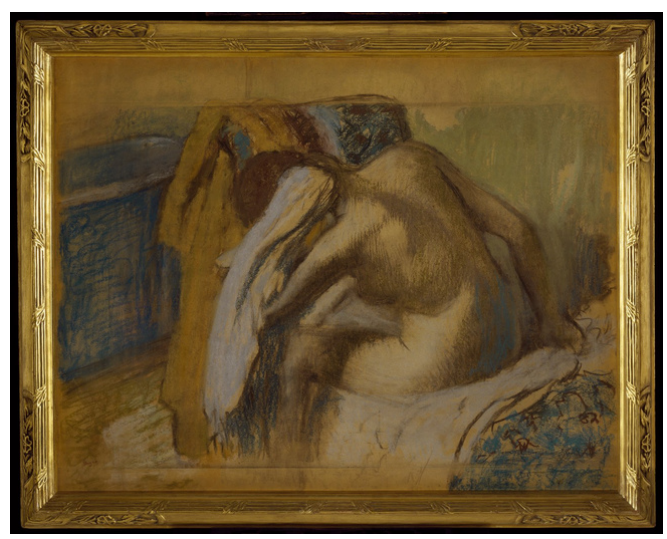

Fig. 4, Edgar Degas, Woman Drying Her Hair, ca. 1889. Pastel and charcoal on tracing paper. Brooklyn Museum, Brooklyn, Museum Collection Fund. Artwork in the public domain; available from: the Brooklyn Museum. [larger image]

The serial quality of Degas's late pastels contrasts with Claude Monet's related pictorial practice of the 1890s. [4] Whereas Monet examined ways in which single subjects such as grainstacks or the façade of the Rouen Cathedral could be rendered in different atmospheric conditions, Degas repeated individual motifs for the purpose of generating new pictorial scenarios and showcasing how the material features of a visual artifact can impact on its meaning. The two versions of After the Bath (fig. 1,2) illustrate this point. Although derived from the same pose, the slightly straighter back of the woman in figure 2 deepens the articulation of the spine, while the higher placement of her left arm allows for a more detailed study of the left deltoid and trapezius (in contrast to the articulation of the right scapula in figure 1).[5] Degas's handling of pastel changes to achieve these different emphases, the vigorous rose and white striations in figure 1 ceding to more blended tones (likely from dampening the pastel) and pronounced shading of the woman's musculature in figure 2. Far from suggesting a unified sequence or a theme and variations, Degas's late pastels are independent works in which the repetition of form permitted both a detailed 
study of human anatomy and a means by which the artist could reflect on his own graphic practice. Each resulting work was, therefore, the staging of a unique experiment that tested the ways in which the performance of drawing connected to, and offered an interpretation of, the visible world. These experiments were not driven simply by changes in graphic style, but also by decisions that Degas took to evidence his works' compositional histories and to make those histories part of their meaning. An important element of this process consisted in incremental changes that Degas made to the supports of his images.

While Degas indulged his pictorial restlessness by recycling individual motifs, he enhanced his creative freedom by reshaping the paper on which he drew. To note just some examples: in the large-scale pastel Woman Drying Her Hair (fig. 4) differently sized strips of paper were added to the top and bottom of the work, thereby slightly squaring the composition; in After the Bath, Woman Drying Herself (fig. 5) a strip of paper at the base extended the overall picture size by approximately one-eighth; Woman with a Towel (fig. 6) was enlarged in similar proportion by a strip of paper at the top. The extent of these alterations varies significantly across the late pastels with some additions taking up nearly one-third of the composition (Seated Woman Adjusting Her Hair, ca. 1884; Courtauld Gallery, London) and others enlarging the background by around an inch (Seated Bather Drying Herself, ca. 1895; private collection).[6]

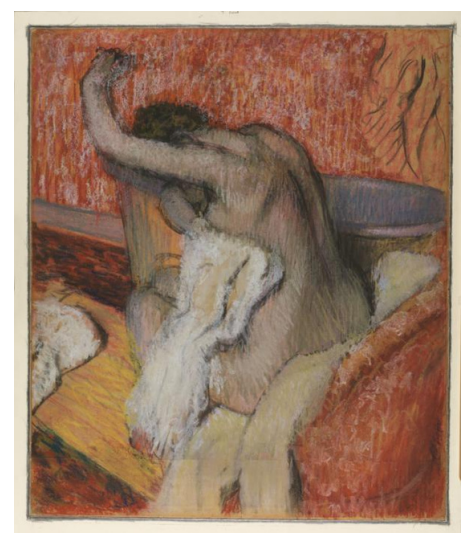

Fig. 5, Edgar Degas, After the Bath, Woman Drying Herself, ca. 1895. Pastel on paper. The Courtauld Gallery, London. Artwork in the public domain; available from: the Courtauld Gallery, London. [larger image] 


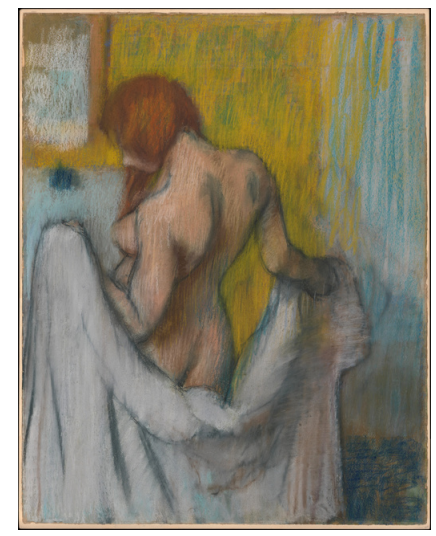

Fig. 6, Edgar Degas, Woman with a Towel, 1894 or 1898. Pastel on cream-colored wove paper with red and blue fibres throughout. The Metropolitan Museum of Art, New York, H.O. Havemeyer Collection, Bequest of Mrs H.O. Havemeyer, 1929. Artwork in the public domain; available from: the Metropolitan Museum of Art, New York. [larger image]

Some of these changes to the support were intended to develop the fictional space around the central figure. In the case of After the Bath, Woman Drying Herself (fig. 5), for example, the additional strip of paper at the base of the image extends the props, balances the composition, and generates a focal point by centering the towel against the woman's ribcage. This structural change heightens the affective impact of the work, as the viewer's eye is drawn to the placement of woman's torso between the softness of the cotton towel and the hard surface of the metal bathtub in the background. Consistent pastel application between the two segments of the support creates a smooth transition over the seam, yet truncated highlights in the blanket over the arm of the chair generate a visual disruption and draw attention to the horizontal fissure between the paper segments. Degas's depiction of a slice of one woman's sensory existence is, therefore, matched by a material assertion of the work's surface that recalls the viewer to his or her own imaginary and physical engagement with the art object.

In her discussion of Degas's late nudes, Carol Armstrong argues that the colors and textures employed in these pastels "have little to do with social description" and often "do not seem to correspond to vision at all."[7] While the former point is in keeping with Degas's increasing emphasis on the recycling of motifs, the latter signals an important paradox. Degas's application of layers of pastel to produce strongly gestural, abstract areas of color generates tension between an anti-mimetic agenda, on the one hand, and a commitment to the human figure, on the other.

The art critic Waldemar George noted this feature of Degas's late works in an essay of 1936 when he positioned Degas as a "patron" of twentieth-century avant-garde painting.

Describing Degas's late "chromatic writing" as a precursor of the pictorial "liberties" taken by Pablo Picasso and Georges Braque, George focused specifically on the way in which Degas dispersed color "without any concern for truth, verisimilitude, credibility."[8] For George, Degas's pursuit of images that defied "optical laws" demonstrated the possibilities of a unique and self-contained "visual logic" that irrevocably freed art from mimesis and 
demonstrated the ongoing relevance of the artist's work to a narrative of twentieth-century European modernism.[9]

The background of After the Bath (fig. 2) is a good illustration of the tensions between naturalism and abstraction in these late works. Devoid of the armchair, tub, and structural differentiation between floor and curtains seen in figure 1, the pastel in the Norton Simon Foundation collection comprises a dynamic, non-naturalistic background of cascading fabrics. Working in complementary colors of red and green, Degas showcases approaches to mark making that range from the descriptive (a white floral pattern), to a fluid cursive, porous highlights, and densely textured areas of opacity. These anti-narrative outbursts of graphic energy occur around the central figure, eliminating depth and offsetting the curves of the woman's body. The work epitomizes a strategy that runs throughout the bather pastels of the 1890s, namely, a drive not simply to create images, but also to interrogate the expressive-and often visually disruptive-possibilities of a work's constituent elements. While the use of color and choice of paper are central to this strategy, Degas's experimentation with the integrity of the background support also plays a key role.[10]

In the case of works that have been produced "in pieces," the oscillation of the viewer's attention between the depicted subject and the uneven textures of the object's surface recalls Richard Wollheim's famous account of "seeing-in" to pictures. [11] According to Wollheim, paintings demonstrate twofoldness when the viewer is simultaneously aware of the subject of the work (its depicted content) and material features such as brush marks, the weave of canvas or paper, watermarks, folds, stains, and other irregularities that are extraneous to the visual fiction. Degas exploits the potential of twofoldness in his late pastels in a distinctive way: by making manifest numerous joins, creases, and discontinuities, he undermines the illusionistic impact of the image and pulls the viewer's attention to the physical qualities of the support and the jigsaw qualities of its composition. Whereas Wollheim describes an act of looking look "through" surface irregularities for the purpose of enjoying the depicted scene, Degas requires the viewer to consider both the subject and the material composition of the object itself. In consequence, the paper support is made aesthetically and materially relevant to the viewer's appreciation of the work.

This point is particularly relevant in light of the type of paper that Degas used for his late pastels. David Bomford notes that tracing paper is not suited to pastel insofar as it has no texture for catching the pigment and has a "bland" surface that is "without character in itself."[12] Starting from this smooth base, Degas enjoyed the liberty of creating a distinctive support that would draw the viewer's attention to the work's material qualities. While fixative helped to build layers of pastel on the paper (thereby enhancing its physical density), additional strips of paper both enlarged the scope of the composition and rendered visible the chronology of its production. Tracing paper need not, therefore, be viewed simply as a material to which Degas turned for the purpose of copying motifs. Rather, it was a type of paper that offered him the freedom to construct unique surface shapes and textures and to communicate the evolution of his pictorial thinking.

While some additions in the works discussed above extend the props surrounding the principal subject, it would be wrong to think that Degas added to the size of his late pastels solely for the purpose of developing their fictional content. Just as abstract areas of pastel 
application defied "optical laws" as George put it, pasted strips of paper could leave provocative spaces of unworked possibility. In After the Bath, Woman Drying Her Feet (fig. 7), the extension to the base of the picture contains nothing other than the artist's signature.[13] Instead of completing the folds of the towel around the woman's feet or depicting the lower section of the tub on the right, the extra strip of paper undermines the mimetic impact of the scene and highlights instead the identity of the work's creator.

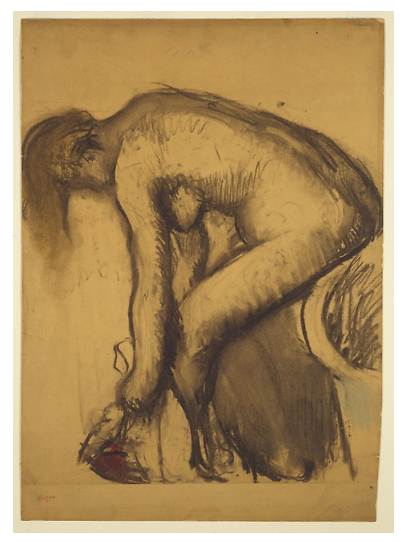

Fig. 7, Edgar Degas, After the Bath, Woman Drying Her Feet, ca. 1900. Charcoal, charcoal wash, and touches of red and yellow and pale blue pastel, with stumping and erasing, on buff wove tracing paper, pieced and laid down on sulphite board. The Art Institute of Chicago, Chicago. Artwork in the public domain; available from: the Art Institute of Chicago. [larger image]

Thin strips of paper were added to the base and to each side of the large-scale composition in charcoal and red chalk entitled Woman Combing her Hair of ca. 1887-90 (fig. 8). It is worth mentioning this work in the context of the present argument for two reasons. First, Degas signs the work in the top righthand corner across the seam between the main sheet of paper and the additional strip (approx. three-quarters of an inch in width), thereby drawing attention to the discontinuous background and to the join itself. Secondly, as Jane Munro notes, the work was published during Degas's lifetime.[14] Here, as in the examples discussed above, this assertion of the work's materiality precludes a passive experience of its content and demands that the viewer attend to the work's qualities as both an image and an object. A black and white reproduction of the drawing was included in Ambroise Vollard's luxury volume, Degas: Quatre-Vingt-Dix-Huit Reproductions signées par Degas (Degas: Ninety-Eight Reproductions Signed by Degas), of 1914.[15] It is therefore fair to say that Degas considered the work to be "finished" (in the sense of "fit for exhibition") despite the presence of visible joins and an unworked background. In consequence, the viewer's awareness of the fractured nature of the support is integral to his or her experience of the work. 


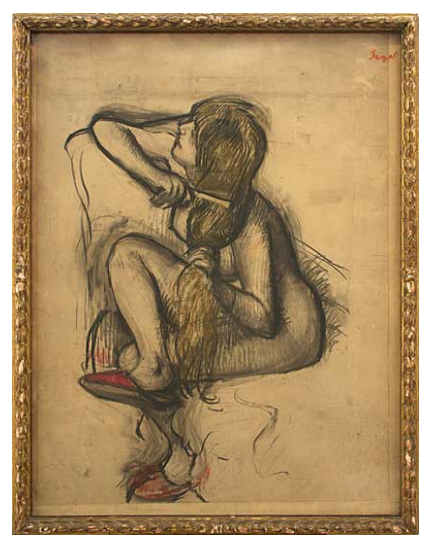

Fig. 8, Edgar Degas, Woman Combing Her Hair, ca. 1887-90. Charcoal and red chalk on tracing paper. Accepted by HM Government in Lieu of Inheritance Tax from the Estate of Stephen Brod and allocated to Pallant House Gallery, Chichester (2016). Artwork in the public domain; available from: Antiques Trade Gazette, 18 April 2016 (www.antiquestradegazette.com). [larger image]

The presence of these blank, but inscribed spaces in Degas's late works on paper is reminiscent of the artist's aborted restoration of his double portrait Monsieur et Madame Édouard Manet (Mr. and Mrs. Édouard Manet; fig. 9). Manet famously sliced off the righthand section of the portrait on the grounds that he objected to the way in which his wife, Suzanne, had been depicted. Degas recovered the work and planned-but failed-to restore it. [16] Although he added a strip of canvas to the side of the image for the purpose of the restoration, he ultimately left the space blank. As in After the Bath, Woman Drying Her Feet (fig. 7), Degas added his signature to the extra piece of canvas. While this may have served as a placeholder pending repair of the work, it also endorsed the work's material (re)composition: it approved the existence of an empty space alongside the principal subject matter, evidenced the biography of the object, and communicated to viewers that the omission of visual information was now part of the work. In these cases, therefore, discontinuous or empty strips of canvas or paper could convey a range of meanings that were not directly relevant to the visual fiction with which they were associated. 


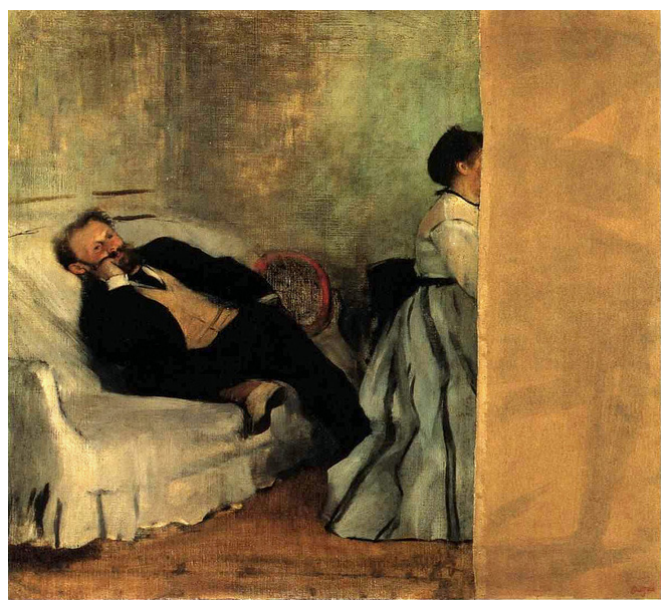

Fig. 9, Edgar Degas, Monsieur et Madame Édouard Manet (Mr. and Mrs. Édouard Manet), ca. 1869. Oil on canvas. Kitakyushu Municipal Museum of Art, Fukuoka. Artwork in the public domain; available from: Wikiart. [larger image]

Various exhibitions have shed light on Degas's approach to composition in his late pastels by drawing attention to the works' material qualities. [17] It is known, for example, that the artist could have used commercial paper that was sufficiently large enough for his ambitions and that the gluing of segments of paper onto card is likely to have been undertaken by a professional Parisian framer-Père Lézin-or, on occasion, by a firm of specialist printmakers, Adam-Dupré.[18]

Technical analysis has also provided insight into the order in which Degas completed individual compositions. The extraordinarily complex work in London's National Gallery (fig. 1 ) is comprised of seven pieces of wove paper.[19] Infrared photographs and a microscopic examination of the surface undertaken by conservators indicate differing densities of pastel application. It seems likely that Degas worked on the two central panels first (having already applied color to the underdrawing) and added to them later.[20] Mapping out the central part of a composition was standard for Degas, who then elaborated further ideas around the primary subject. Another clue to the order of composition is that fixative had to be applied to the earliest pastel segments in order to secure them prior to gluing them to the underlying millboard.[21]

The question arises as to how this process-based style of production impacts on conceptions of Degas's draftsmanship and the relationship of his late work to ideas about pictorial composition that developed in art critical discourses from the mid- to late nineteenth century. Throughout his career, Degas was described as a thinker who solved problems through the act of drawing. Émile Zola referred to him as a "scientific spirit" and a "meticulous draftsman," while Paul Valéry emphasized his "knowing art."[22] Yet it was that very combination of craftsmanship and analysis that many twentieth-century modernists used for the purposes of consigning Degas to history. In the case of Maurice de Vlaminck, for example, Degas was remembered as a "bourgeois artist" whose predilection for "academic 
drawing" revealed an outmoded indebtedness to the works of Jean-Auguste-Dominique Ingres.[23]

The presence of uneven surfaces and the visibility of seams in Degas's late pastels challenge both of these views. Countering the image of Degas as an artist who had plotted out an entire composition prior to its execution, evidence of an accretive compositional practice imbues these works with a contingent quality. Despite his assertion that there was no art less spontaneous than his own, Degas makes the viewer witness to a series of decisions that developed during the course of a work's production, thereby suggesting that the image could have cohered differently at any point prior to gluing. [24] Degas may have remained indebted to academic drawing throughout his career, but he also challenged that tradition by questioning the ways in which the material and graphic qualities of an artwork cohere to create unified meaning. Arguably, it was precisely Degas's skill in academic drawing that makes the compositional experimentation discussed in this article so subversive. As Valéry put it, the "division" in Degas's creative persona provoked by a commitment to both classicism and innovation cast him as a singularly "anxious character in the tragi-comedy of modern art."[25]

Leaving traces of a work's compositional history on its surface was a potent statement at the end of the nineteenth century. The visibility of individual segments evoked notions of the fragment that had been a familiar feature of Romantic aesthetics much earlier in the century. Charles Rosen and Henri Zerner have examined the popularity of the literary and visual fragment in Romanticism, linking this to a widespread enthusiasm for ruins and to an increasing appreciation of sketchy finishes that left individual brush marks perceptible on the surface of paintings. The fragment was expressively powerful, Rosen and Zerner argue, because it attacked "the integrity of the classical work" and eluded familiar categories within hierarchies of artistic genres.[26] The fragment could, therefore, communicate nostalgia for the missing whole while paradoxically offering itself as a complete, but unorthodox work of art in its own right.[27]

Michael Fried identifies a change in conceptions of the fragment in the later decades of the century by contrasting the values ascribed to the "morceau" (piece) and the "tableau" (painting) in art critical discourses of the 1860s and 1870s. [28] Focusing on responses to works produced by the "Generation of 1863"-Manet, Henri Fantin-Latour, James Abbott McNeill Whistler, and Alphonse Legros-Fried notes the importance that critics accorded to the pictorial unity of a finished painting ("tableau") as opposed to works that were considered to be mere fragments or "agglomerations of fragments" ("morceaux").[29] The pursuit of "compositional and coloristic unity" for the purpose of achieving "formal and expressive closure" in painting remained, Fried argues, an ideal that persisted in art critical debate into the closing decades of the nineteenth century. [30] He does not discuss Degas in connection with this theme, although he tantalizingly suggests that Degas's art "makes historical sense only when it is seen in relation to the concerns of the generation of 1863. " [31]

Degas's predilection for working "in pieces" toward the end of his career may be viewed as just such an act of self-placement in relation to conceptions of the aesthetic role of the fragment in the nineteenth century. Although the works under discussion in this article were 
produced in pastel, they are nevertheless salient to debates about the ways in which a picture should or should not function as an expressive whole. Degas's late bather pastels present a distinctive perspective on this problematic. As is evident from the examples discussed above, in the majority of cases the viewer perceives the female bathers as integral subjects (their bodies are not fragmented) while also noticing that each image's support consists of two or more segments (the whole is visually discontinuous). In contrast to Rosen and Zerner's characterization of the Romantic fragment, Degas's innovation is to highlight the material fragmentation of the art object while retaining the integrity of its central subject.

Degas's late pastels also problematize any easy opposition between the "morceau" and the "tableau" insofar as their material form disrupts the visual unity of the composition to differing extents. In Woman with a Towel (fig. 6), for example, pastel is applied in continuous marks over the seam at the top of the picture in a way that blurs the boundary between the two pieces of paper.[32] In the upper right of the background, above the woman's head, vibrant ochre streaks zigzag across the two segments and highlight the continuity of the artist's gestures over the divide. As the eye travels along the join to the left, however, a change in the style of pastel handling creates a noticeably different effect in the depiction of an object that Anne Maheux identifies as a gilded mirror. [33] As white highlights have been rubbed across the two pieces of paper (likely by turning the crayon on its side), pastel has settled into the seam. This draws attention to the vertical discontinuity of the support and generates an uneven visual effect along a single horizontal plane.

A more significant disruption to the visual field occurs in a work now housed in the collection of the Art Institute of Chicago titled The Bathers (fig. 10). This sequential, multi-figure composition depicts four individuals at different stages of bathing and dressing by a river. While Kendall identifies a quotation from Nicolas Poussin's The Baptism of Christ (1641-42; National Gallery of Art, Washington, DC) in the figure putting on her stockings, a similar motif (and set of consecutive states) had been employed in a contemporary setting in the late 1880 s by Georges Seurat in his large-scale canvas The Models (1886-88; The Barnes Foundation, Philadelphia).[34] Like many of the other works discussed in this article, Degas's pastel was found in his studio after his death. It is signed in the lower left-hand corner.[35] The central panel contains the four bathers, while two additional strips of paper extend the pictorial space above and below the central subjects. [36] 


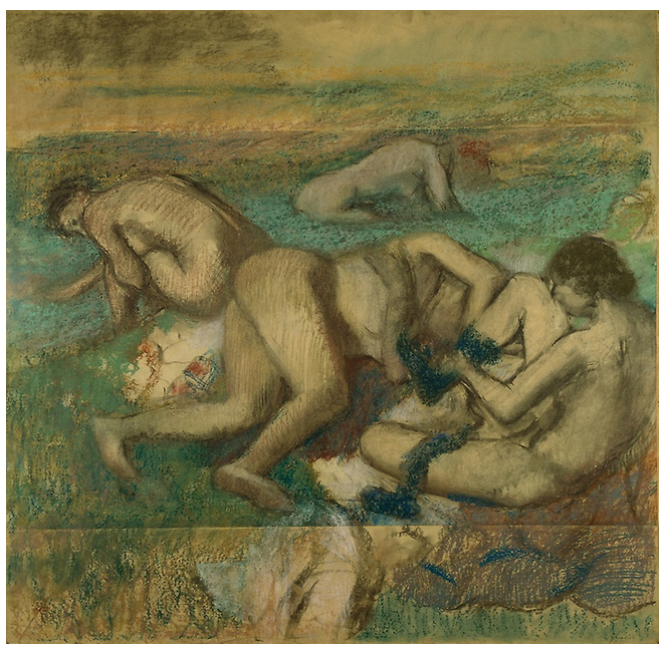

Fig. 10, Edgar Degas, The Bathers, ca. 1885-95. Pastel and charcoal on tracing paper, pieced and mounted on cardboard. Art Institute of Chicago, Chicago. Artwork in the public domain; available from: the Art Institute of Chicago. [larger image]

As in the other works under discussion, the bathers are depicted as integral figures. Indeed, the extensions to the work generate an internal frame that contains and isolates their bodies. While the additional panels combine effectively with the principal color scheme of the central section, they nevertheless generate an uneven perspective that both extends and disrupts the pictorial space. More so than in the pastels discussed above, the additions to this background support question the extent to which a composition communicates unified meaning in the face of radical visual discontinuity.

The poet and critic Yves Bonnefoy has argued that an image's support is a "delimitation or framing which suggests that the things and beings the image seems to evoke are situated in an authentic place, with its own space and even its own light."[37] The relationship between image and support in The Bathers troubles this idea. In contrast to the paintings by Poussin and Seurat mentioned above, Degas's segmented pastel undermines illusionistic space. While the central panel suggests a place within which the bathers are located, the framing effect generated by the extensions undoes the visual integrity of that space and hence of the work as a whole. If, as Elizabeth Watson and Jared Bark have suggested, Degas often used frames to enhance "the paradoxical flatness and depth" of his canvases, the framing effect of paper strips opens a similar line of questioning in the medium of pastel. [38]

Degas's willingness to draw the viewer's attention simultaneously to the subject and its support-to an entire work and its constituent elements-represented a new step in thinking about the role of the fragment in visual art. Suggesting neither a nostalgia for lost wholeness, nor a definitive abandonment of pictorial unity, Degas's late pastels require the viewer to pursue different visual trajectories and to consider how graphic and material elements can combine and recombine to create multiple networks of sense within a single object. 
This was a technique that embedded Degas's late compositional practice within avant-garde literary currents in the final decade of the nineteenth century. Specifically, there is a strong link between this aspect of Degas's pictorial experimentation and the work of a poet whose creative and critical writings were important to both the development of nineteenth-century art criticism and the modernist enterprise of the twentieth century: Stéphane Mallarmé. Mallarmé had published a significant amount of art criticism during the 1870s, including discussions of Degas's work. [39] Poet and painter moved in the same social circle, often meeting at Mallarmé's Tuesday evening literary salon ("les mardis") or Berthe Morisot's home, and in 1895 Degas photographed the poet standing next to Pierre-Auguste Renoir (fig. 11).[40] In 1897 Mallarmé published what would become his most influential poem "Un Coup de dés jamais n'abolira le hasard" (A Dice Throw Never Will Abolish Chance) in the review Cosmopolis, although an edition using the correct typography was not published until 1914 (fig. 12).

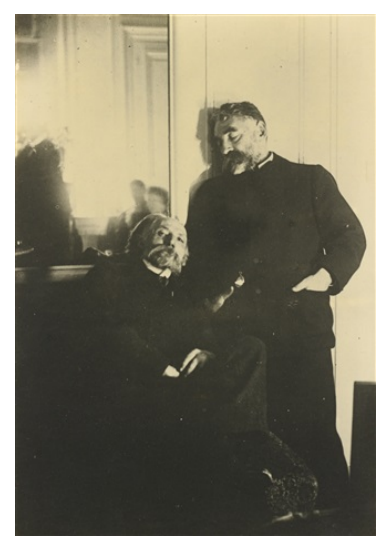

Fig. 11, Edgar Degas, Pierre-Auguste Renoir and Stéphane Mallarmé, December 1895. Gelatin silver print. Museum of Modern Art, New York, Gift of Paul F. Walter. Artwork in the public domain; available from: the Museum of Modern Art, New York. [larger image]

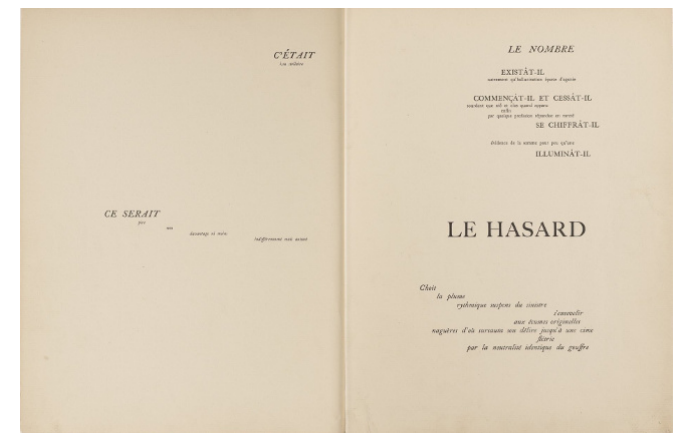

Fig. 12, Stéphane Mallarmé, "Un Coup de dés jamais n'abolira le hasard" (A Dice Throw Never Will Abolish Chance) (Paris: Nouvelle Revue Française, 1914), 18-19. Artwork in the public domain; available from: the Bibliothèque Nationale de France, Paris. [larger image] 
With its multiple fonts and unconventional page layout, "Un Coup de dés" is a poem that asks its readers to focus not only on the meaning of the words printed on the page, but also on their visual appearance and on the blank spaces that infiltrate the poetic line. Ostensibly taking as its subject the story of a shipwreck, the poem eludes any straightforward narrative trajectory. Instead, readers are required to trace multiple patterns of sense by pursuing words with matching fonts, following typographical patterns instead of syntactical units, and reading in multiple directions. Like Degas's pastels of the 1890s, "Un Coup de dés" is at once a single poem and a series of pieces that can be fitted together in different ways. It makes use of language, typeface, and blank space to generate multiple layers of meaning. Mirroring the central dilemma examined in this article, "Un Coup de dés" communicates through different semantic networks while eschewing a definitive pattern. As Malcolm Bowie aptly put it:

Mallarmé makes us think again about the directions in which artistic coherence may be pursued and the verbal methods by which it may be articulated. He invites us to take risks. He exposes us to a special kind of anxiety by making it extremely hard for us to extract an idea from a text in a simple, manageable form: we are forced to leave it where it was, hedged about and baffled by its cognates, collaterals and contraries.[41]

This article has argued that a similar aesthetic can be found in Degas's mobile compositional practice of the 1890s. Indeed, the "anxiety" referred to by Bowie recalls Valéry's description of Degas as an "anxious character," divided by radically contrasting approaches to the creation of meaning in visual form. By inviting the appreciation of "whole" works composed of fragments and by exploring multiple-sometimes inconsistent-relationships between surface marks and a fragmented background support, Degas challenged prevailing conceptions of pictorial unity and expanded the means by which an artwork could communicate both materially and visually. He thus imposes his own "anxiety" on the viewer, who is forced to accept that the different interpretive paths traced in and around the image may never cohere into a single, stable form.

The adventurous, mobile compositional practice found in Degas's late pastels-complete with its manifestation of discontinuities and surface disruptions-anticipated more radical experimentation with the unity of the artwork in the twentieth century. From Henri Matisse's interrogation of the relationship between the human figure and compartmentalized backgrounds in large-scale paintings such as Bathers by a River (1909-17; Art Institute of Chicago, Chicago) and The Moroccans (1915-16; Museum of Modern Art, New York), to the radical questioning of the integrity of form in cubist painting and surrealist photomontage, or the multi-panel compositions of Sean Scully, Robert Mangold, and Tacita Dean, Degas's late work exploited the expressive possibilities of caesuras, interruptions, and contingencies in visual composition.[42]

Attending to the ways in which images relate to their material supports is fundamental to the aesthetic impact of Degas's late pastels. By inviting viewers to look at and through their subject matter, these works prompt reflection on debates about the integrity of the artwork that were potent throughout the nineteenth century and that were contested with renewed vigor in the twentieth century. By drawing a comparison between the composition of these 
works and Mallarmé's poetic in "Un Coup de dés," I have sought to broaden the context of Degas's late practice and to show a further way in which the artist's works of the 1890s contributed to debates about the creation of meaning from fragmented forms and materials. Taking up one of Mallarmé's own descriptions of "Un Coup de dés," Degas's late pastels may be said to manifest "prismatic subdivisions" of an idea in which each segment of a work holds the viewer's imagination in a state of perpetually unresolved suspense. [43]

This article examines how Edgar Degas challenged the compositional and communicative integrity of the artwork by pinning together pieces of paper, pasting them on card, and developing motifs over joins between the segments. Through a close reading of Degas's late bather pastels, the article locates Degas's accretive working method within debates about the role of the "fragment" in mid- to late nineteenth-century art critical discourses. It is argued that focusing on Degas's decision to create works "in pieces" is important for understanding both his place in nineteenth-century art history and the legacy of his oeuvre in European modernism.

Email the author: k.j.brown[at]lboro.ac.uk

\section{Notes}

[1] Theodore Reff, "The Technical Aspects of Degas's Art," Metropolitan Museum Journal 4 (1971): 141-66; Richard Kendall, Degas Beyond Impressionism, exh. cat. (London: National Gallery, 1996), 82; Richard Thomson, The Private Degas (London: Herbert Press, 1987), 11328; David Bomford, with contributions from Jo Kirby and Ashok Roy, "Degas at Work," in Degas: Art in the Making, David Bomford et al. (London: National Gallery, 2004), 29-35; George T. M. Shackelford, "Le Corps transformé: Les Derniers nus de Degas," in Degas et le nu, exh. cat., George T. M. Shackelford and Xavier Rey (Paris: Hazan, 2012), 185-239; Line Clause Pedersen, "Degas' Method," in Degas' Method, exh. cat., ed. Line Clause Pedersen (Copenhagen: Ny Carlsberg Glyptothek, 2013), 85-86; Jane Munro, "The Nude," in Degas: A Passion for Perfection, ed. Jane Munro (New Haven: Yale University Press, 2017), 78-115.

[2] Kendall, Degas Beyond Impressionism, 82.

[3] For a discussion of Degas's use of photography, see Malcolm Daniel et al., Edgar Degas, Photographer, exh. cat. (New York: Metropolitan Museum of Art, 1998); Elizabeth C. Childs, "Habits of the Eye: Degas, Photography, and Modes of Vision," in The Artist and the Camera: Degas to Picasso, exh. cat., ed. Dorothy Kosinski (San Francisco: Museum of Modern Art, 2000), 70-87.

[4] See also Pedersen's discussion of this contrast in Degas' Method, 85.

[5] Although After the Bath in the Norton Simon Foundation collection is dated 1885, the date was added after the artist's signature and is thought to be incorrect. Kendall dates the work as ca. 1890-93, Degas Beyond Impressionism, 233. See also Richard Thomson's discussion of anatomy in the late nudes in Degas: The Nudes (London: Thames \& Hudson, 1988), 182-83.

[6] Paul-André Lemoisne, Degas et son œuvre, vol. 3 of 4 (Paris: Arts et Métiers Graphiques, 1946-49; repr., New York: Garland, 1984), pl. 781 and 1340. Bomford notes the presence of precise instructions from Degas to the colleur (framer) concerning the addition of strips to an earlier work, The Dance Lesson (ca. 1879; The Metropolitan Museum of Art, New York). See Bomford et al., "Degas at Work," 32-33.

[7] Carol Armstrong, Odd Man Out: Readings of the Work and Reputation of Edgar Degas (Chicago: University of Chicago Press, 1983), 197.

[8] Waldemar George, "Fuvres de vieillesse de Degas," La Renaissance 1-2 (1936): 4. 
[9] Ibid.

[10] Anne Maheux discusses the choices that Degas made in relation to paper type and tone (including leaving sections of the support exposed) in "Looking into Degas's Pastel Technique," in Degas Pastels, Jean Sutherland Boggs and Anne Maheux (London: Thames \& Hudson, 1992), 20-23.

[11] Richard Wollheim, Painting as an Art (London: Thames \& Hudson, 1987), 46-80. I have also considered the relevance of Wollheim's account of twofoldness in relation to Degas's darkfield monotypes. See Kathryn Brown, "Touch and Vision in Edgar Degas's Darkfield Monotypes," Print Quarterly 31, no. 4 (2014): 402.

[12] Bomford et al., "Degas at Work," 30.

[13] For related variations on this motif see Lemoisne, Degas et son œuvre, vol. 3: pl. 138084.

[14] Jane Munro, "The Nude," 107.

[15] Ambroise Vollard, Degas: Quatre-Vingt-Dix-Huit Reproductions signées par Degas (Paris: Ambroise Vollard, 1914). The work was included as PI. LXXXIII (Femme se peignant, dessin rehaussé) (Woman Combing Her Hair, drawing heightened with color).

[16] Degas's propensity to rework "completed" compositions was also a noted aspect of his pictorial practice. See Reff, "The Technical Aspects of Degas's Art," 163-65; Paul Valéry, Degas Danse Dessin (1936; repr., Paris: Flammarion, 1965), 116-17. See also Marni Kessler's detailed discussion of Degas's Monsieur and Madame Manet in "Édouard Manet's Ham and Suzanne's Lost Body in Edgar Degas's Salon," in Contemporary French Civilization (2017): 42 (nos. 3-4), 279-300 (287).

[17] See in particular Kendall, Degas Beyond Impressionism; Pedersen, "Degas' Method"; David Bomford et al., "Degas at Work."

[18] Kendall, Degas Beyond Impressionism, 86; Bomford et al., "Degas at Work," 127. Anne Maheux notes that tracing paper was commercially available in rolls of different dimensions from 1865. Boggs and Maheux, Degas Pastels, 25.

[19] Bomford et al., "Degas at Work," 124.

[20] Ibid., 126.

[21] For a discussion of Degas's use of fixatives, see Boggs and Maheux, Degas Pastels, 3133. Conservators at London's National Gallery suggest that After the Bath, Woman Drying Herself may contain a layer of supporting paper between the tracing paper and the underlying millboard. See Bomford et al., "Degas at Work," 126.

[22] Émile Zola, "Salon de 1876," in Écrits sur l'art, ed. Jean-Pierre Leduc-Adine (Paris: Gallimard, 1991), 314, 353; Valéry, Degas Danse Dessin, 11-13. Jane Munro notes that this image of Degas was developed, in part, to counter the charge of repetition and reliance on a narrow range of subjects in his later art. See Munro, "Introduction," in Degas: A Passion for Perfection, 14.

[23] Maurice de Vlaminck, Portraits avant décès (Paris: Flammarion, 1943), 142.

[24] Degas is reputed to have made this comment to George Moore. For a discussion of the relevance of this comment to Degas's conception of tradition see Ann Dumas, "Degas and his Collection," in The Private Collection of Edgar Degas, exh. cat., Ann Dumas et al. (New York: Metropolitan Museum of Art, 1997), 25-26. See also Kendall on Degas's almost "arbitrary decisiveness" regarding the moment at which the pieces were glued onto card. Kendall, Degas Beyond Impressionism, 86; and Munro on the relationship between drawing and a "cultivation of the contingent," Munro, "Introduction," in Degas: A Passion for Perfection, 13.

[25] Valéry, Degas Danse Dessin, 151.

[26] Charles Rosen and Henri Zerner, Romanticism and Realism: The Mythology of Nineteenth-Century Art (New York: Norton, 1984), 24.

[27] See also Glenn W. Most's discussion of nostalgia for the missing whole in his essay "On Fragments," in The Fragment: An Incomplete History, ed. William Tronzo (Los Angeles: Getty Research Institute, 2009), 9-22.

[28] Michael Fried, Manet's Modernism or, The Face of Painting in the 1860s (Chicago: Chicago University Press, 1996), 278.

[29] Ibid., 142.

[30] Ibid., 267.

[31] Ibid., 11. 
[32] Kendall notes other, rarer examples where Degas camouflages surface joins by depicting props such as pillars and curtains. Kendall, Degas Beyond Impressionism, 86.

[33] See Anne Maheux's catalogue commentary on Woman with a Towel in Boggs and Maheux, Degas Pastels, 152. Maheux goes on to note that the presence of pastel bridging the joint suggests that the additional strip of paper was added quite early in the compositional process.

[34] Kendall, Degas Beyond Impressionism, 278.

[35] Christopher Riopelle notes that Degas often withheld works from the market and debates the implications of signed versus unsigned pieces. While the question of "finish" seemed permanently open in Degas's case, Riopelle suggests that Degas may also have retained works for the purpose of including them in his own planned (though unrealized) private museum. See Christopher Riopelle, "Edgar Degas: Illustrious and Unknown" in "Degas at Work," Bomford et al., 17.

[36] A sense of how Degas built up the image can be gained by contrasting the work with Deux femmes au bain (Two Bathers) (Lemoisne, Degas et son œuvre, vol. 3, pl. 1080) that was produced on a smaller sheet of paper that isolates the two bathers on the left.

[37] Yves Bonnefoy, Poetry and Photography, trans. Chris Turner (London: Seagull Books, 2017), 8.

[38] This is consistent with Degas's investigation of the effects of frames more generally. See Elizabeth Waston and Jared Bark, "'Pictures Properly Framed': Degas and Innovation in Impressionist Frames," The Burlington Magazine 150, no. 1266 (2008): 611. See also Kendall, Degas Beyond Impressionism, 86.

[39] See Stéphane Mallarmé, "The Impressionists and Édouard Manet (1876)," Fuvres complètes, vol. 2, ed. Bertrand Marchal (Paris: Gallimard, Bibliothèque de la Pléiade, 2003), 444-70.

[40] For further detail, see Rosemary Lloyd, Mallarmé: The Poet and His Circle (Ithaca, NY: Cornell University Press, 1999), 146-48; Jean-Michel Nectoux, "Mallarmé, Degas et les petites Manet. Sur quatre photographies d'Edgar Degas," in Mallarmé ou l'obscurité lumineuse, ed. Bertrand Marchal and Jean-Luc Steinmetz, (Paris: Hermann, 1999), 343-56.

[41] Malcolm Bowie, Mallarmé and the Art of Being Difficult (Cambridge: Cambridge University Press, 1975), 17.

[42] Reff explores Degas's sculpture Little Dancer Aged Fourteen as a precursor of surrealism and twentieth-century assemblage. Reff, "The Technical Aspects of Degas's Art," 158. See also Kendall's discussion of Degas's late pastels as precursors of seriality in works by Warhol and Duchamp in Kendall, Degas Beyond Impressionism, 84. For reasons discussed in this article, my view differs from Kendall on the nature of "seriality" in the cases of Degas and Warhol.

[43] Stéphane Mallarmé, "Observation relative au poème Un Coup de dés jamais n'abolira de hasard par Stéphane Mallarmé," Fuvres complètes, vol. 1, ed. Bertrand Marchal (Paris:

Gallimard, Bibliothèque de la Pléiade, 1998), 391. 


\section{Illustrations}

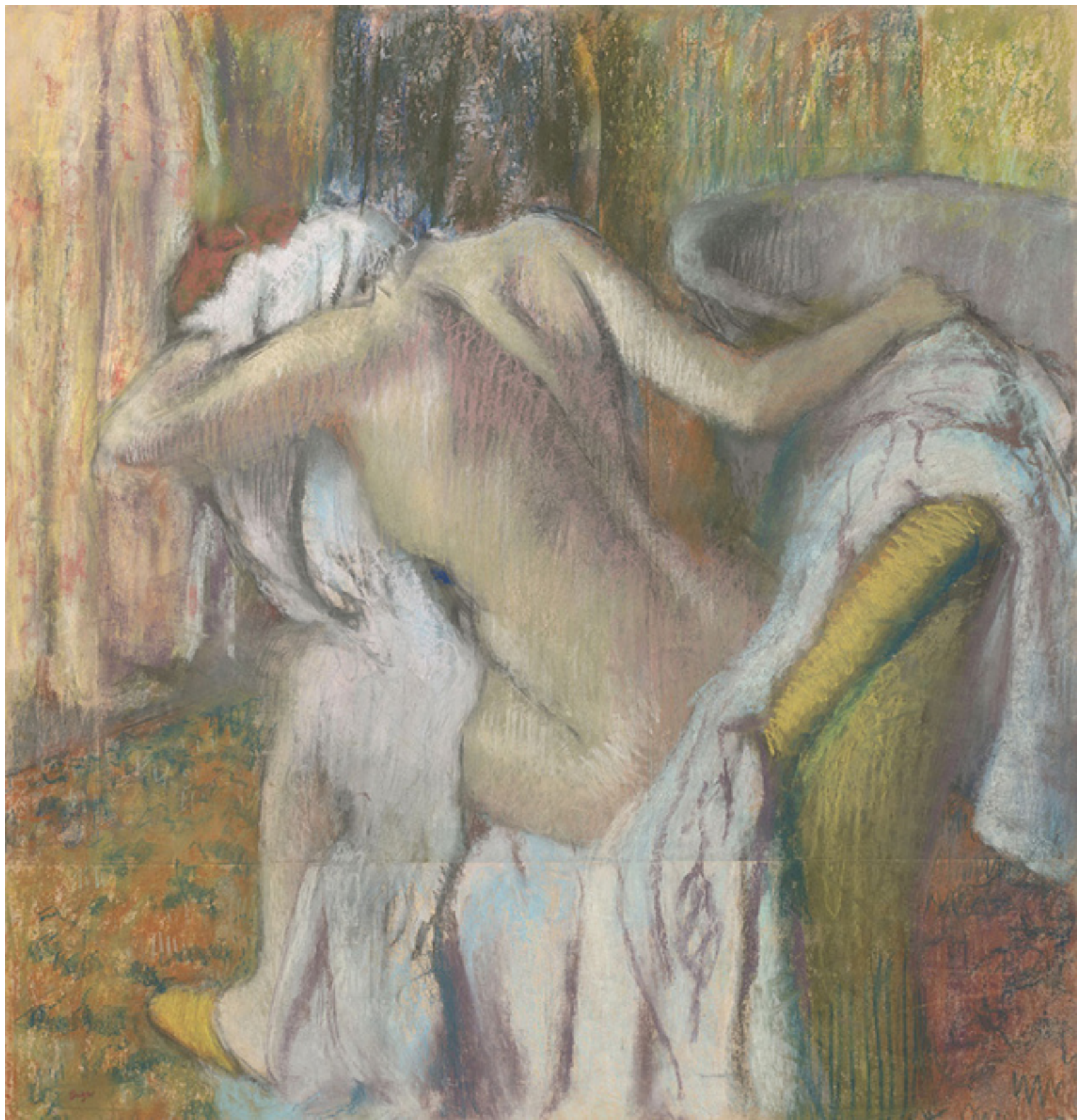

Fig. 1, Edgar Degas, After the Bath, Woman Drying Herself, ca. 1890-95. Pastel on wove paper laid on millboard. The National Gallery, London. Artwork in the public domain; available from: the National Gallery, London. [return to text] 
Brown: Degas in Pieces: Form and Fragment in the Late Bather Pastels Nineteenth-Century Art Worldwide 17, no. 2 (Autumn 2018)

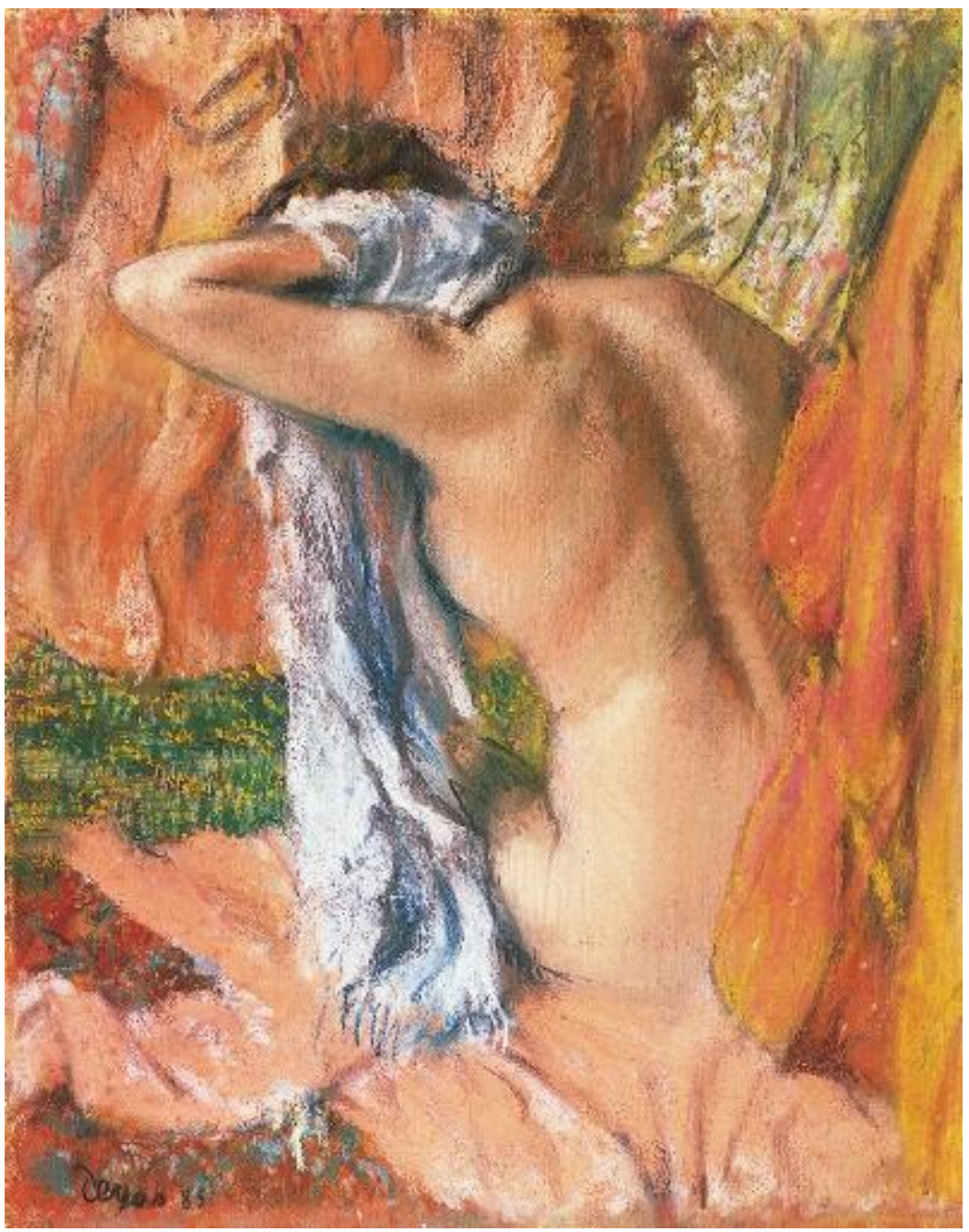

Fig. 2, Edgar Degas, After the Bath, ca. 1890-93. Pastel on paper mounted on cardboard. The Norton Simon Foundation, Pasadena. Artwork in the public domain; available from: the Norton Simon Foundation. [return to text] 


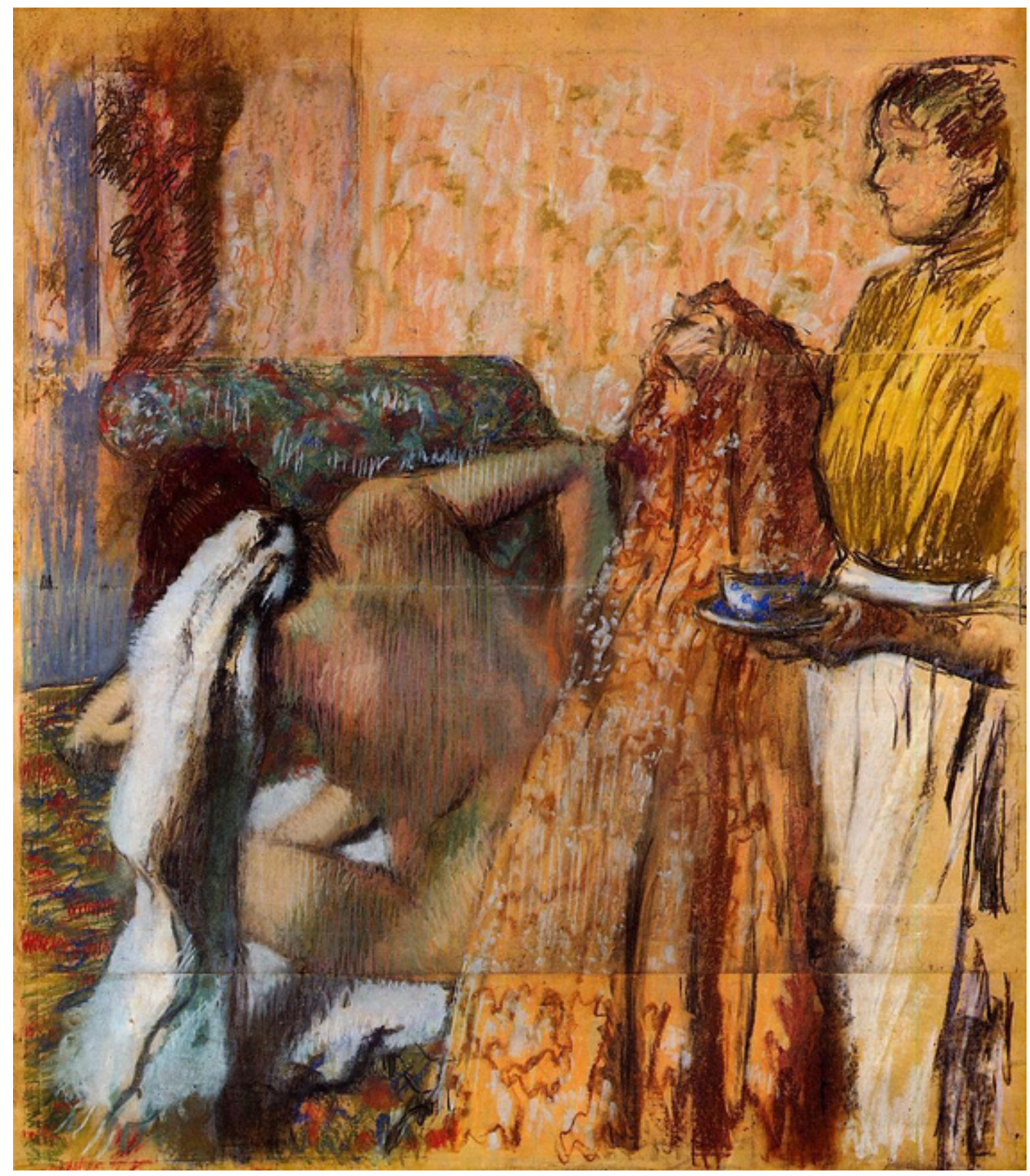

Fig. 3, Edgar Degas, Breakfast After the Bath, ca. 1893-98. Pastel on tracing paper. Kunstmuseum Winterthur, Winterthur. Artwork in the public domain; available from: the.athenaeum.org. [return to text] 
Brown: Degas in Pieces: Form and Fragment in the Late Bather Pastels Nineteenth-Century Art Worldwide 17, no. 2 (Autumn 2018)

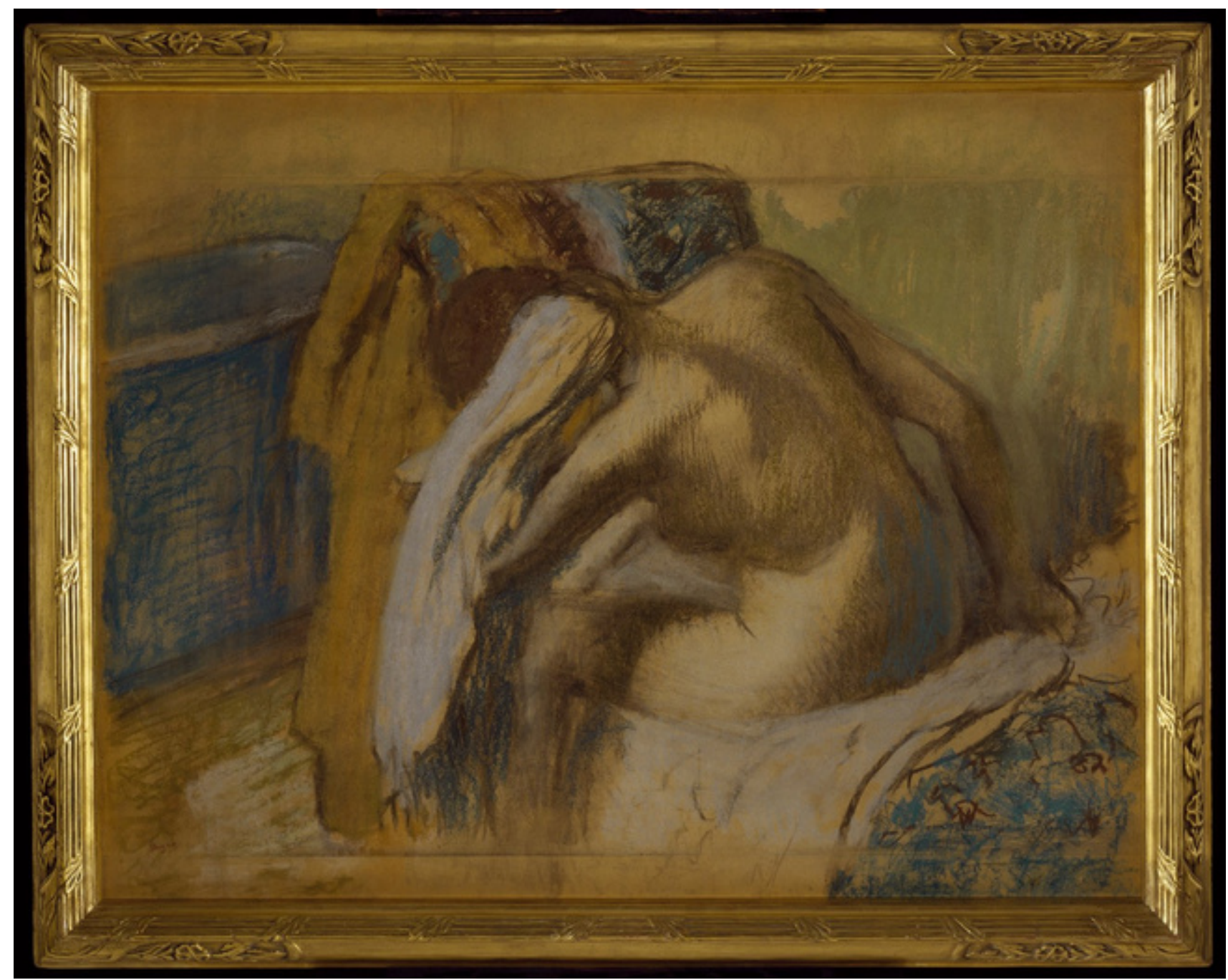

Fig. 4, Edgar Degas, Woman Drying Her Hair, ca. 1889. Pastel and charcoal on tracing paper. Brooklyn Museum, Brooklyn, Museum Collection Fund. Artwork in the public domain; available from: the Brooklyn Museum. [return to text] 


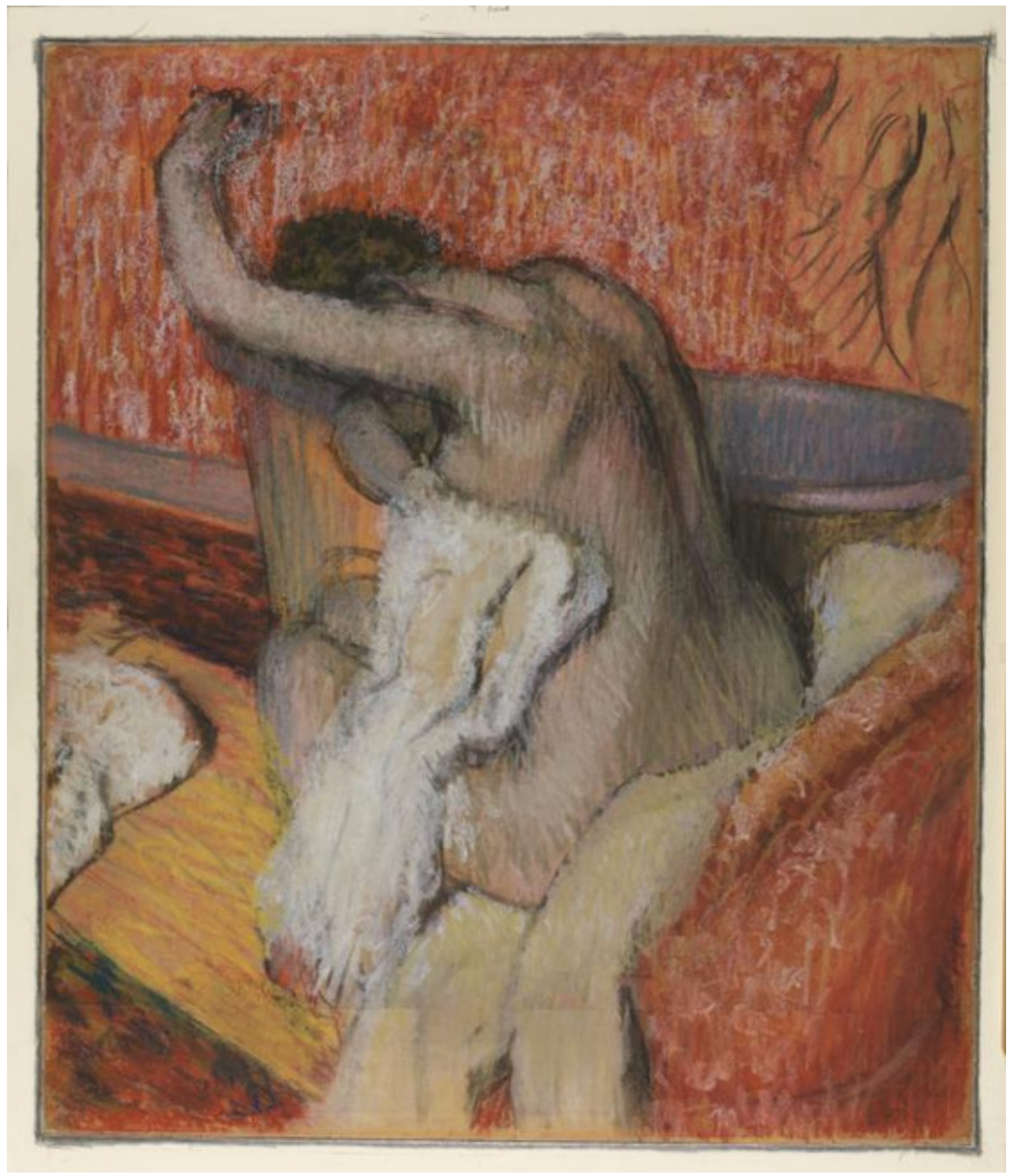

Fig. 5, Edgar Degas, After the Bath, Woman Drying Herself, ca. 1895. Pastel on paper. The Courtauld Gallery, London. Artwork in the public domain; available from: the Courtauld Gallery, London. [return to text] 
Brown: Degas in Pieces: Form and Fragment in the Late Bather Pastels

Nineteenth-Century Art Worldwide 17, no. 2 (Autumn 2018)

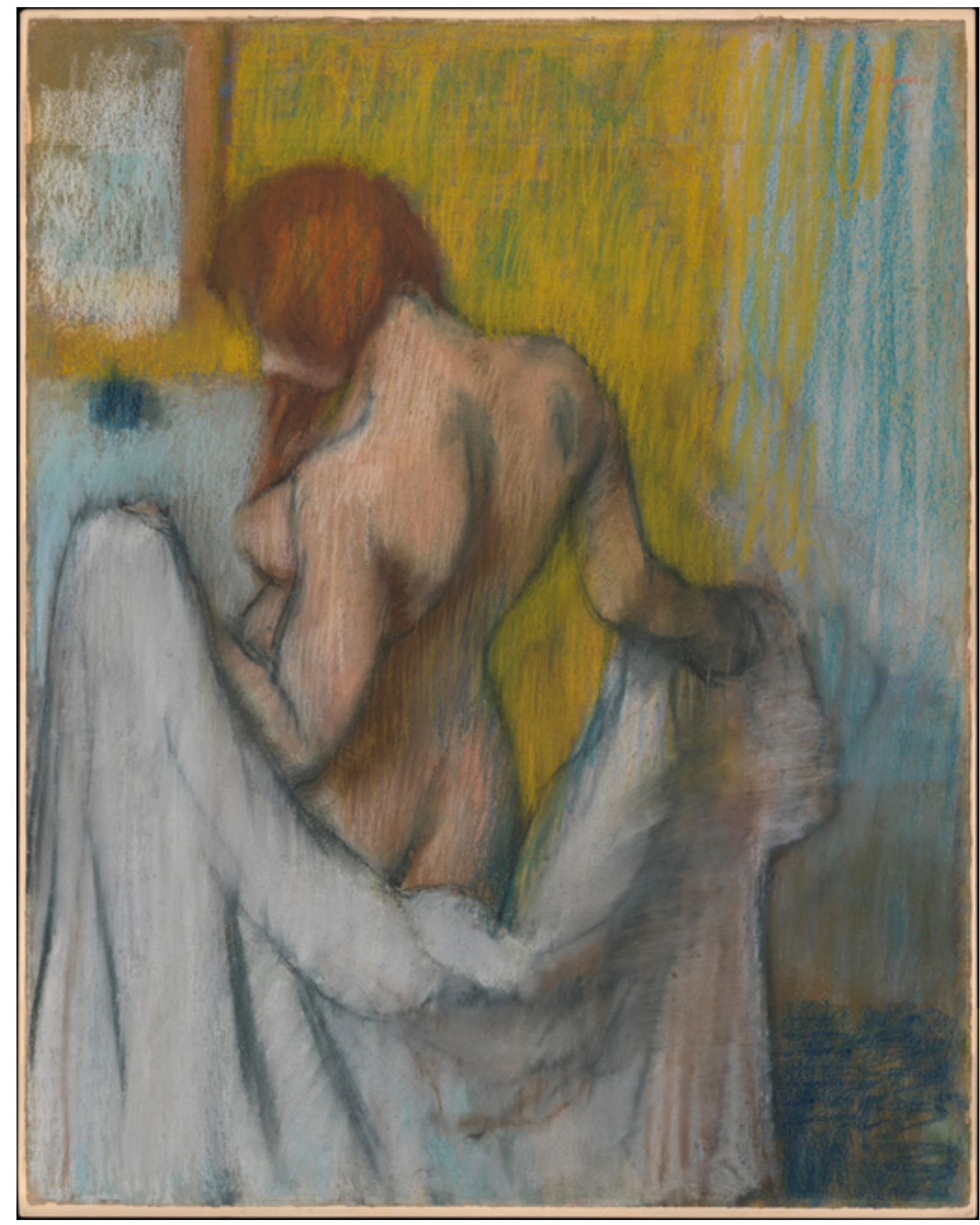

Fig. 6, Edgar Degas, Woman with a Towel, 1894 or 1898. Pastel on cream-colored wove paper with red and blue fibres throughout. The Metropolitan Museum of Art, New York, H.O. Havemeyer Collection, Bequest of Mrs H.O. Havemeyer, 1929. Artwork in the public domain; available from: the Metropolitan Museum of Art, New York. [return to text] 


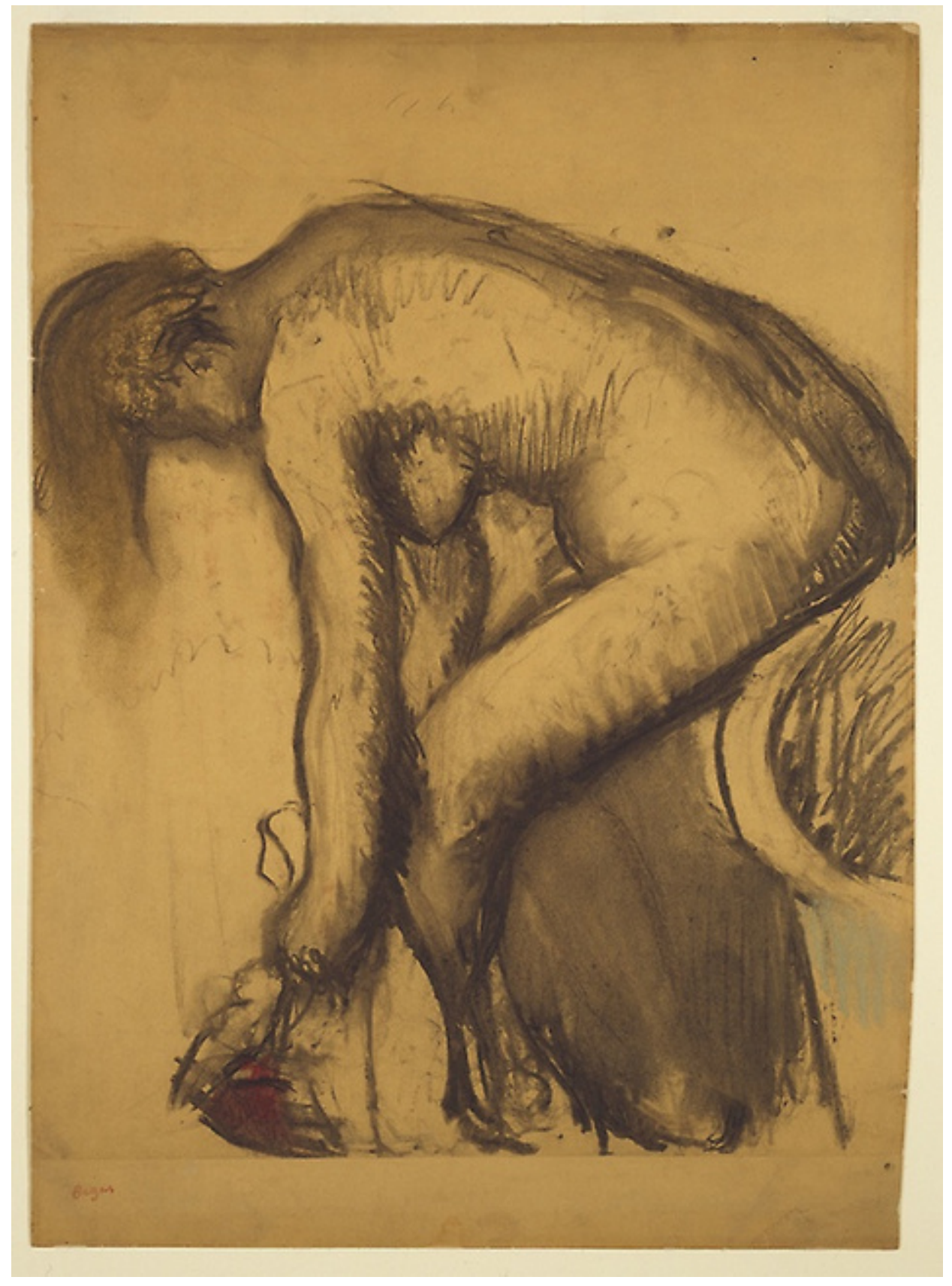

Fig. 7, Edgar Degas, After the Bath, Woman Drying Her Feet, ca. 1900. Charcoal, charcoal wash, and touches of red and yellow and pale blue pastel, with stumping and erasing, on buff wove tracing paper, pieced and laid down on sulphite board. The Art Institute of Chicago, Chicago. Artwork in the public domain; available from: the Art Institute of Chicago. [return to text] 


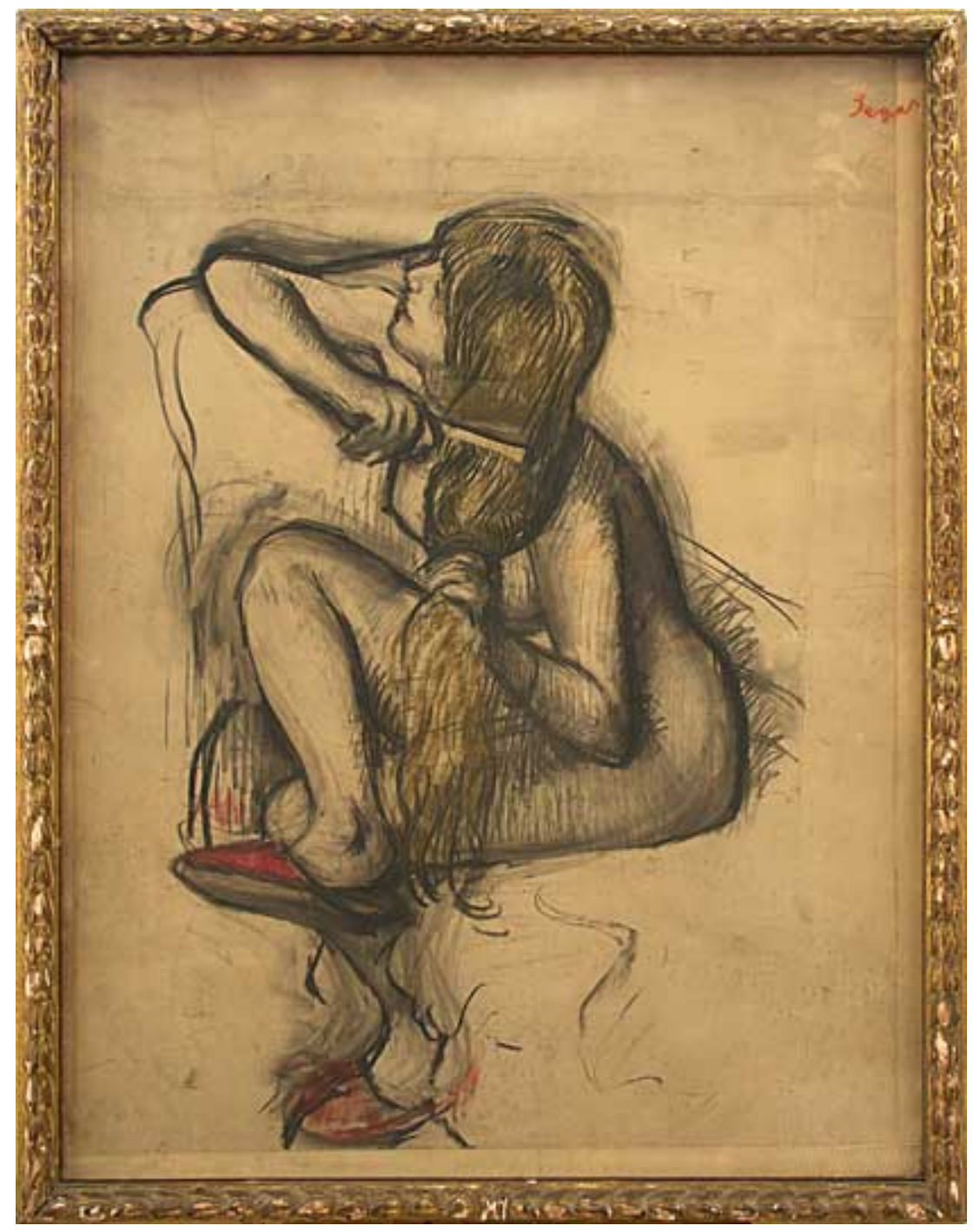

Fig. 8, Edgar Degas, Woman Combing Her Hair, ca. 1887-90. Charcoal and red chalk on tracing paper. Accepted by HM Government in Lieu of Inheritance Tax from the Estate of Stephen Brod and allocated to Pallant House Gallery, Chichester (2016). Artwork in the public domain; available from: Antiques Trade Gazette, 18 April 2016 (www.antiquestradegazette.com). [return to text] 


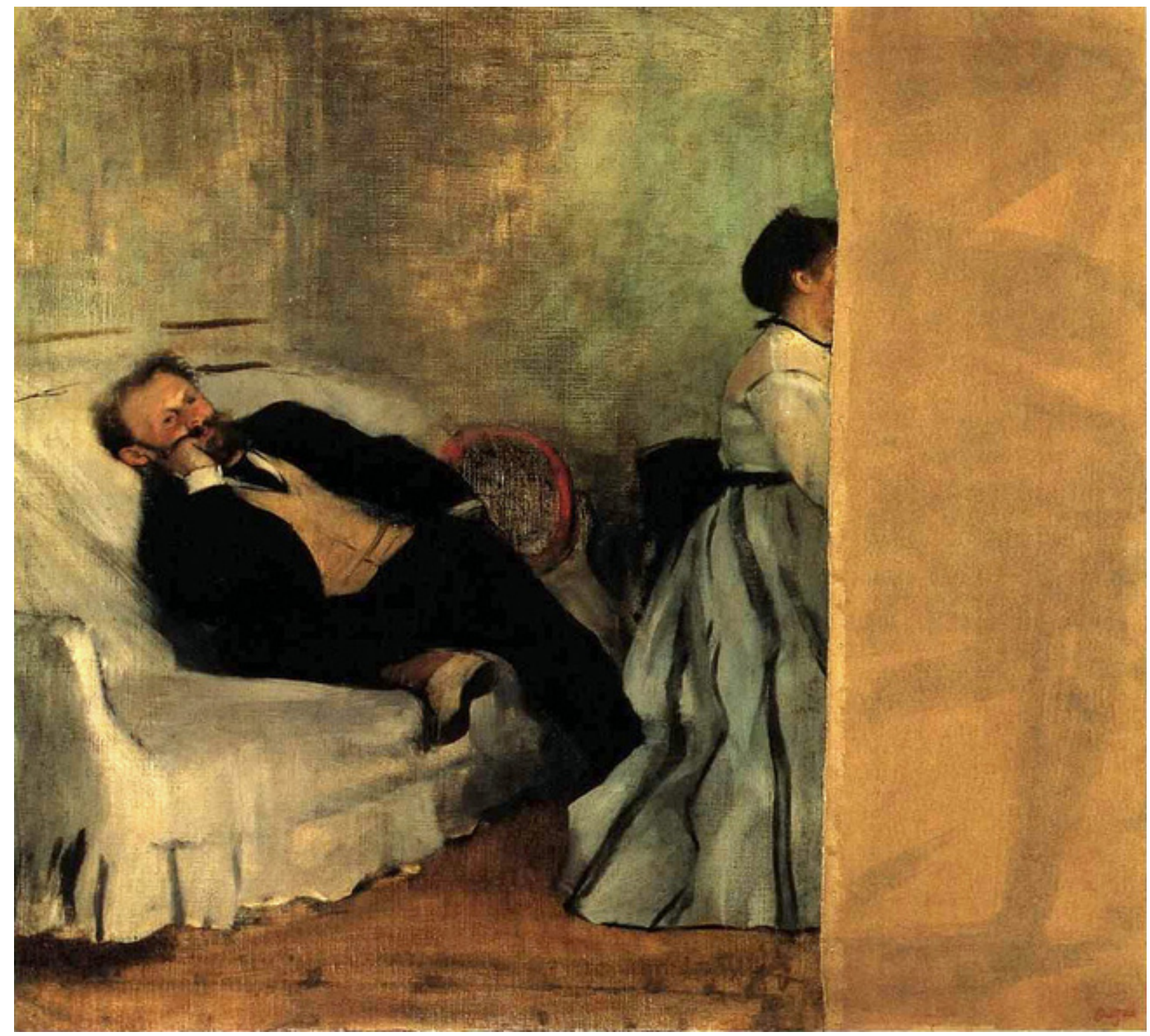

Fig. 9, Edgar Degas, Monsieur et Madame Édouard Manet (Mr. and Mrs. Édouard Manet), ca. 1869. Oil on canvas. Kitakyushu Municipal Museum of Art, Fukuoka. Artwork in the public domain; available from: Wikiart. [return to text] 


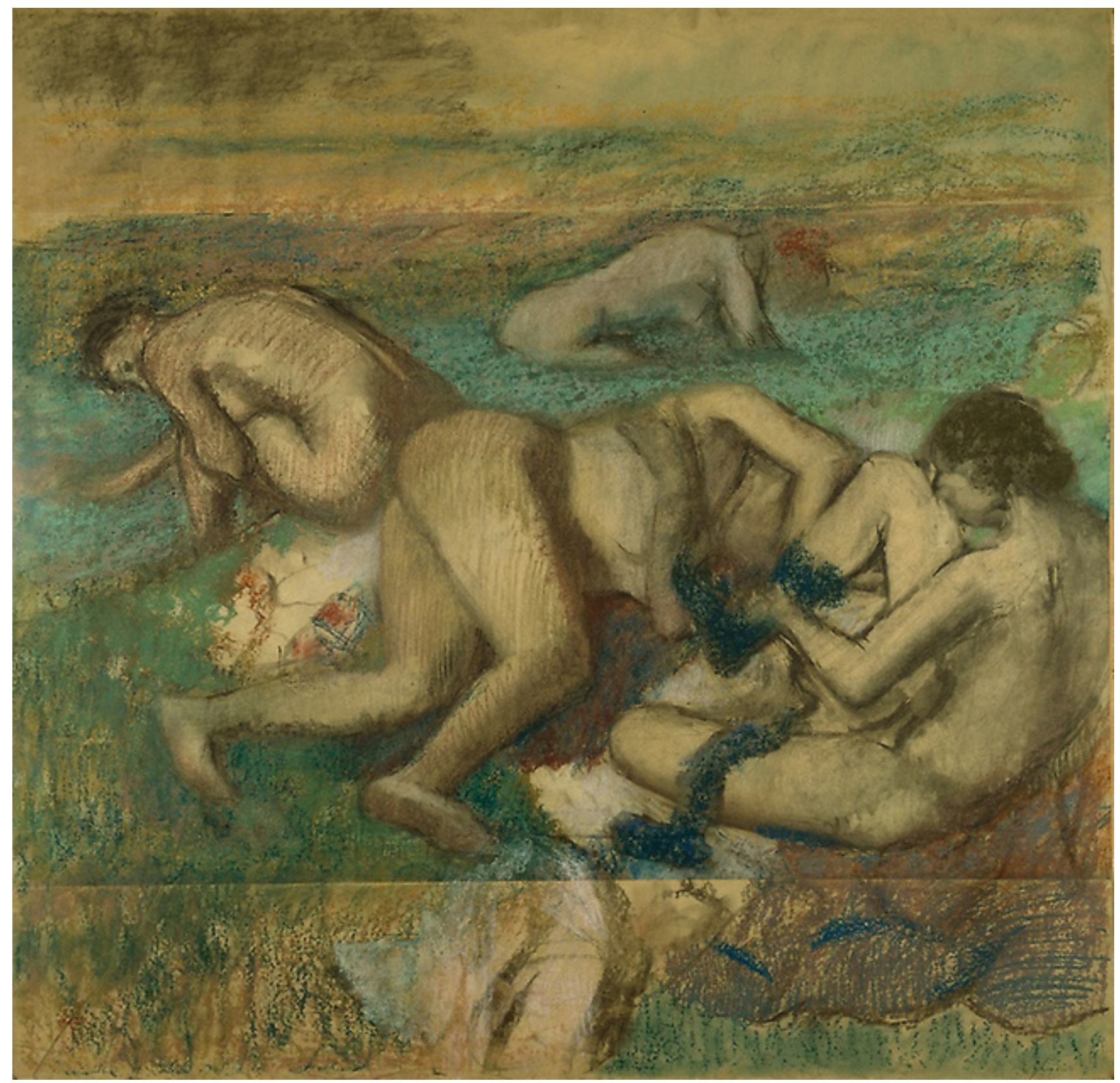

Fig. 10, Edgar Degas, The Bathers, ca. 1885-95. Pastel and charcoal on tracing paper, pieced and mounted on cardboard. Art Institute of Chicago, Chicago. Artwork in the public domain; available from: the Art Institute of Chicago. [return to text] 


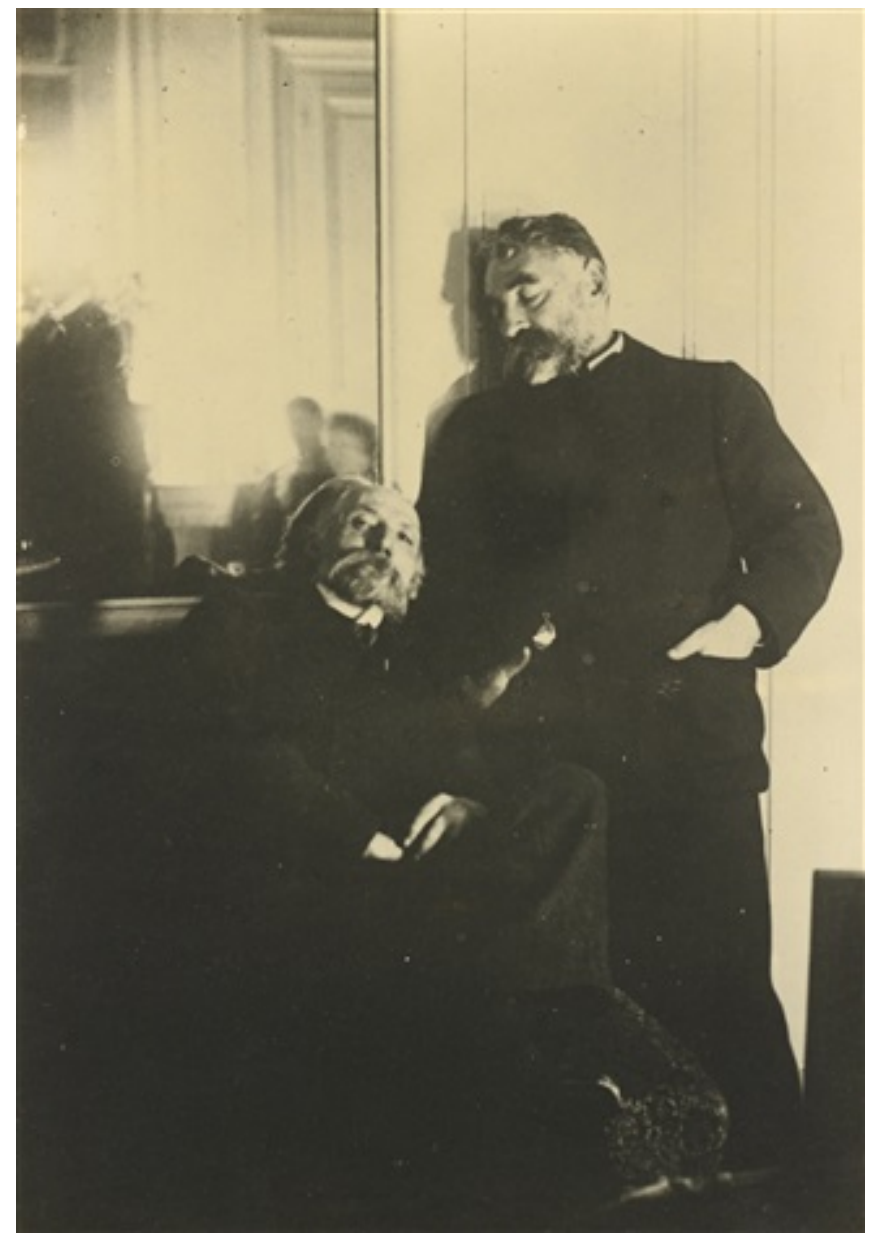

Fig. 11, Edgar Degas, Pierre-Auguste Renoir and Stéphane Mallarmé, December 1895. Gelatin silver print. Museum of Modern Art, New York, Gift of Paul F. Walter. Artwork in the public domain; available from: the Museum of Modern Art, New York. [return to text] 
Brown: Degas in Pieces: Form and Fragment in the Late Bather Pastels

Nineteenth-Century Art Worldwide 17, no. 2 (Autumn 2018)

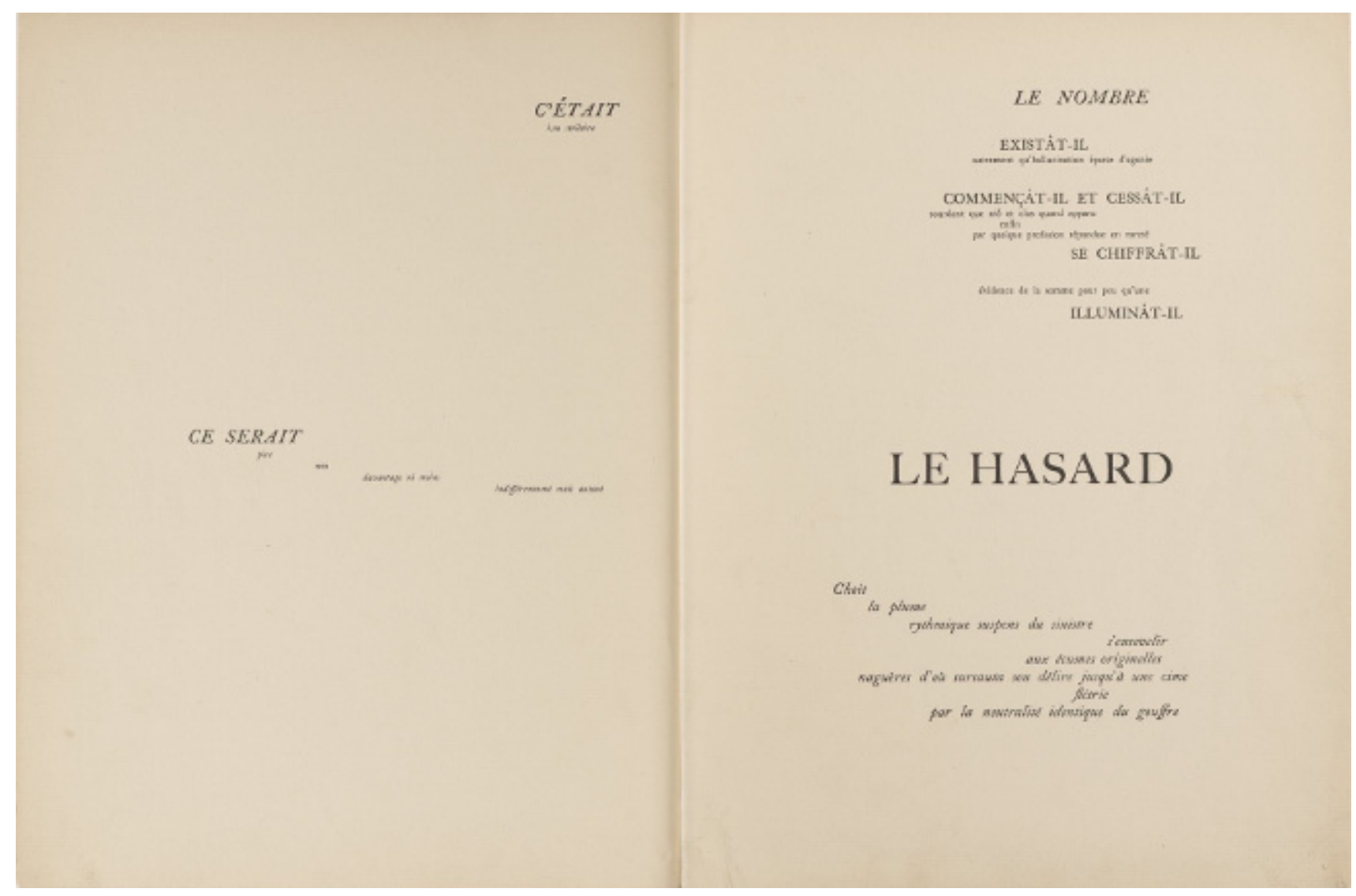

Fig. 12, Stéphane Mallarmé, "Un Coup de dés jamais n'abolira le hasard" (A Dice Throw Never Will Abolish Chance) (Paris: Nouvelle Revue Française, 1914), 18-19. Artwork in the public domain; available from: the Bibliothèque Nationale de France, Paris. [return to text] 